Article

\title{
Anti-Bacterial and Anti-Fungal Activity of Xanthones Obtained via Semi-Synthetic Modification of $\alpha$-Mangostin from Garcinia mangostana
}

\author{
Srinivasan Narasimhan ${ }^{1}$, Shanmugam Maheshwaran ${ }^{1}$, Imad A. Abu-Yousef ${ }^{2}$, \\ Amin F. Majdalawieh ${ }^{2}$, Janarthanam Rethavathi ${ }^{1}$, Prince Edwin Das ${ }^{1}$ and Palmiro Poltronieri ${ }^{3, *}$ \\ 1 Asthagiri Herbal Research Foundation, 162A, Perungudi Industrial Estate, Perungudi, \\ Chennai 600096, India; asthagiri.herbal@gmail.com (S.N.); mahesh7605@yahoo.co.in (S.M.); \\ rethavathij@gmail.com (J.R.); prince.ahrf@gmail.com (P.E.D.) \\ 2 Department of Biology, Chemistry and Environmental Sciences, American University of Sharjah, \\ P.O. Box 26666 Sharjah, United Arab Emirates; iabuyousef@aus.edu (I.A.A.-Y.); \\ amajdalawieh@aus.edu (A.F.M.) \\ 3 Institute of Sciences of Food Productions, CNR-ISPA, Lecce 73100, Italy \\ * Correspondence: palmiro.poltronieri@ispa.cnr.it; Tel.: +39-083-242-2609; Fax: +39-083-242-2620
}

Academic Editors: Daniela Barlocco and Fiorella Meneghetti

Received: 14 December 2016; Accepted: 8 February 2017; Published: 12 February 2017

\begin{abstract}
The microbial contamination in food packaging has been a major concern that has paved the way to search for novel, natural anti-microbial agents, such as modified $\alpha$-mangostin. In the present study, twelve synthetic analogs were obtained through semi-synthetic modification of $\alpha$-mangostin by Ritter reaction, reduction by palladium-carbon (Pd-C), alkylation, and acetylation. The evaluation of the anti-microbial potential of the synthetic analogs showed higher bactericidal activity than the parent molecule. The anti-microbial studies proved that I E showed high anti-bacterial activity whereas I I showed the highest anti-fungal activity. Due to their microbicidal potential, modified $\alpha$-mangostin derivatives could be utilized as active anti-microbial agents in materials for the biomedical and food industry.
\end{abstract}

Keywords: $\alpha$-mangostin; anti-bacterial; anti-fungal; packaging; textiles; biomedical device; semi-synthetic modification

\section{Introduction}

The fruit of Garcinia mangostana Linn. (mangosteen), of the family Guttiferae, has been used in Asian traditional medicines for the treatment of skin infections, wounds, diarrhea, dysentery, suppuration, leucorrhea, chronic ulcers, and gonorrhea [1,2]. In addition, mangosteen with essential minerals is commercially used as dietary supplement for cancer patients [3]. The pericarp of the fruit contains high amounts of xanthones, such as $\alpha$-mangostin (Figure 1), $\beta$-mangostin, $\gamma$-mangostin, etc., and considerable amounts of other bioactive compounds, such as terpenes, anthocyanins, tannins, flavonoids and polyphenols [4].

Xanthones are naturally-occurring compounds with a distinct chemical structure, known as tricyclic aromatic system, with known antibacterial properties [5]. Natural compounds with antibacterial properties may be applied to treat local infections [5-7], wounds and lesions difficult to heal, circumventing antibiotic resistant pathogens with multidrug resistance (MDR) genes, or may be combined with antibiotics to increase their effect. Therefore, studies on bacteria inhibition in vitro or in vivo have been performed on a wide array of natural compounds and peptides [8]. In microbiology, the minimum inhibitory concentration (MIC) is the lowest concentration of a chemical that prevents 
visible growth of a bacterium (bacteriostatic activity), whereas the minimum bactericidal concentration $(\mathrm{MBC})$ is the concentration that results in microbial death. Among the pathogens developing antibiotic resistances, Pseudomonas aeruginosa and Staphylococcus aureus (S. aureus) are largely spread in hospitals and healthcare units $[9,10]$.<smiles>COc1c(O)cc2oc3cc(O)c(CC=C(C)C)c(O)c3c(=O)c2c1CC=C(C)C</smiles>

Figure 1. Structure of $\alpha$-mangostin.

In the literature, mangosteen fruit extracts were shown to contain different xanthones, identified by HPLC analysis: $\alpha$-mangostin, $\beta$-mangostin, $\gamma$-mangostin, 8 -desoxygartanin and gartanin, two isoprenylated xanthones, and 9-hydroxycalabaxanthone [11]. $\alpha$-Mangostin (3,6,8-trihydroxy2-methoxy-1,7-bis(3-methyl but-2-enyl)xanthen-9-one) is a compound purified as a yellow crystalline solid, with molecular mass $410.45 \mathrm{~g} / \mathrm{mol}$, having a xanthone core structure. It is prepared by heating of phenyl salicylate (salol). It is used in preparation of xanthydrol, which is used for the determination of urea levels in the blood.

Recent reports have revealed that $\alpha$-mangostin from G. mangostana fruit possesses several medicinal properties, such as anti-microbial activity against bacteria [4,12-18], anti-oxidant and neuro-protective activity [19-22], lipase inhibition [23], and anti-inflammatory and anti-cancer properties [24]. Biologically active molecules from medicinal plants are utilized as therapeutic agents, but most of the secondary metabolites do not exhibit optimum efficacy. This is due to the lack of specificity and the absence of biologically active functional groups. Thus, by elucidating the structure of the active compound and the pharmacophores, the functional groups are considered as essential for the bioactivity of a compound. Since $\alpha$ - and non- $\alpha$-mangostin xanthones have been shown to possess anti-bacterial activity, especially against Gram-positive bacteria [12-18], it is most probable that semi-synthetic analogs would be produced with enhanced anti-bacterial activity. In order to increase the bioactivity and antibacterial properties of $\alpha$-mangostin, semi-synthetic modification of the compound was performed by several authors, to lead to more active compounds [25-29], with no excessive toxicity. Alongside their anti-microbial properties, the synthetic analogs possess wound healing and anti-inflammatory activity and, hence, they could be exploited in the treatment of skin infections.

Following the discovery of the medicinal properties of the synthetic analogs, it is suggested that these analogs possess better therapeutic value than the parent molecule and are potential drug candidates for application as antimicrobials. It has been envisaged that mangosteen xanthones may be applied in several fields and industries, such as textiles, fabrics, and polymers for medical devices and biomaterials for applications in biomedicine [30-32], in biomaterials for oral hygiene and prevention of dental caries [30], in materials preventing biofilm formation [31], and wrapping foil polymers for food packaging [32]. However, it should be demonstrated that these new compounds are non-toxic and safe, and the derived materials do not release them too fast, possibly being covalently linked, to maintain the bioactivity for longer periods. In addition, pathogens are able to survive on steel surfaces and in pipelines where food products are processed, establishing biofilms. Therefore, it is of utmost importance to find new treatments of surfaces and processing lines in the food industry in order to eliminate bacterial contaminations. Several approaches have been proposed to release of active ingredients to the surface and kill the micro-organisms. For example, Poverenov and colleagues prepared numerous active anti-microbial surfaces on the basis of polymers, cellulose, and glass, with 
potent inhibition against Bacillus cereus (B. cereus), Alicyclobacillus acidoterrestris (A. acidoterrestris), Escherichia coli (E. coli), and Pseudomonas aeruginosa (P. aeruginosa) [12-16]. Similar research on anti-microbial food-contact materials were developed based on curcumin [33-35], polyphenols and natural compounds [36-38], essential oils to control pest pathogens [39], active-passive modified atmosphere for microbial control [40,41], and various polymeric-based anti-microbial films [28-32]. Using nanotechnological approaches, new materials based on the antimicrobial property of silver nanoparticles have been studied and produced [42-45].

The perishable foods market is in the need of anti-microbial materials due to economic losses caused by bacterial and fungal growth on foods throughout the entire food supply chain. Such anti-microbial materials should extend the shelf-life of the product on the market shelves up to the consumer table. One challenge is to find methods for improved treatment (i.e., modified atmosphere, type of film, packages composed by various active materials) and application of effective, safe anti-bacterial and anti-fungal compounds [46-52]. These methods may ensure the safety of foods and alleviate the economic losses due to food deterioration. It is envisaged that new anti-microbial compounds could be incorporated in food packaging and films to improve the shelf-life of ready-to-eat foods and packaged fresh products.

In parallel to these studies, other recent reports described similar antibacterial properties in xanthones such as mangiferin from edible plants, as well as from other medicinal plants $[53,54]$.

In the field of polymer preparation, electro-spinning techniques have been applied to G. mangostana extracts, with good results in formation of polylactic acid fiber mats to be used in wound dressing [31]. Electro-spinning allows the deposition of small and medium sized molecules on the surface of a forming polymer [31]. In addition, during the spinning and deposition of the bioactive compounds, eventual solvents present as residues of extraction or purification steps may be evaporated, reducing the possibility of contamination of material being in contact with food products. Furthermore, other deposition techniques may be applied with higher performance and improved purity of xanthones to become part of the polymer. Considering a covalent linkage of the bioactive core inside the polymer, a preliminary study examined functionalized polyxanthones in the form of poly-azoxanthone esters (PAXA), through polycondensation, and showed their applicability in food packaging and in pharmaceutical industry [32].

In search for new anti-bacterial agents we performed semi-synthetic modification of $\alpha$-mangostin using Ritter reaction, reduction by palladium-carbon (Pd-C), alkylation and acetylation to improve the bioactivity of the base compound. In this study, we describe the selective enrichment of $\alpha$-mangostin (demonstrated by the NMR peaks and HPLC graphs) its semi-synthetic modification, the products generated, their chemical structure, and the inhibition activity against four pathogens, two Gram-positive and two Gram-negative bacteria, and two fungi, evaluated as diameter or halo of growth inhibition. Herein, we studied the anti-microbial activity of $\alpha$-mangostin and its synthetic analogs and confirmed the development of new anti-microbial xanthones with higher antibacterial and antifungal activity. The candidate molecules with higher bioactivity may be applied in the composition of antimicrobial textiles and polymers that could find applications in biomedical devices and in food packaging.

\section{Results}

\section{1. $\alpha$-Mangostin Isolation and Purification}

$\alpha$-Mangostin was isolated from the dried fruits of G. mangostana using ethyl acetate and yielded $26 \mathrm{~g}(26 \%)$ of dried ethyl acetate crude extract. The crude extract subjected to column chromatography with ethyl acetate and hexane yielded 5-6 g of pure $\alpha$-mangostin and the purity was confirmed as $95 \%$ using HPLC. The structural characterization of the pure $\alpha$-mangostin (I) using ${ }^{1} \mathrm{H}-\mathrm{NMR}$ spectra, ${ }^{13} \mathrm{C}-\mathrm{NMR}$ spectra, IR spectrum and high-resolution mass spectra is available in Supplementary materials. 


\subsection{Synthetic Modifications}

Following the isolation, $\alpha$-mangostin was subjected to a series of chemical reactions to alter the core structure (Figure 2).

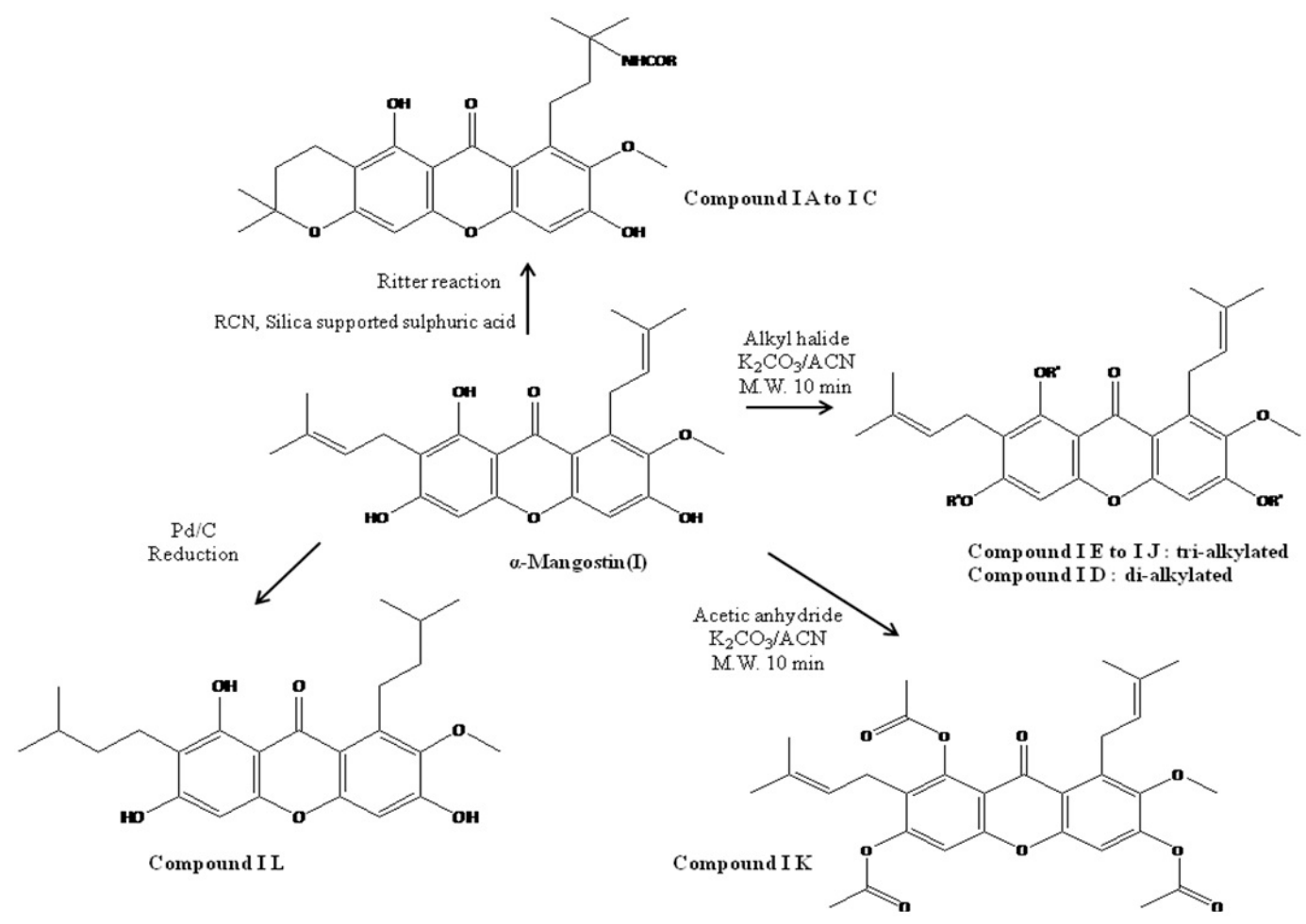

Figure 2. Reaction scheme leading to different derivatives.

The basic core structure xanthone (anthraquinone) was conserved intact while the functional iso-prenyl and phenolic hydroxy groups were subjected to semi-synthetic modification. Twelve different semi-synthetic derivatives were obtained (Table 1), each containing new key moieties that were evaluated to detect the anti-microbial activity against various bacterial and fungal cultures.

(I D), the alkylated product of $\alpha$-mangostin with ethyl iodide, was found to be a di-alkylated product. All other alkylations using the exact same reaction conditions reported in the table resulted in tri-alkylated products. In the Ritter reaction, the addition of acetonitrile, followed by intra-molecular addition of $-\mathrm{OH}$ to isoprene unit gave ether (or) pyran ring structures. Addition of acetonitrile is followed by hydration to produce amide. This reaction is general for all the nitrile reaction products studied (I A to I C). Compound ID, reaction of $\alpha$-mangostin with ethyl iodide, produced mainly the di-alkylated product, probably due to the possibility of ether cleavage of reaction product $\mathrm{HI}$ during the reaction. All other alkylation reactions carried out with alkyl-bromide yielded only tri-alkylated products (I E to I J).

Table 1. $\alpha$-Mangostin and its synthetic derivatives.

\begin{tabular}{|c|c|c|c|c|c|}
\hline S. No. & $\begin{array}{l}\text { Compound } \\
\text { Information }\end{array}$ & Structure & $\begin{array}{c}\text { Reaction of } \\
\alpha \text {-Mangostin with }\end{array}$ & $\begin{array}{l}\text { Molecular } \\
\text { Formula }\end{array}$ & Mass \\
\hline 1. & $\alpha$-Mangostin & & - & $\mathrm{C}_{24} \mathrm{H}_{26} \mathrm{O}_{6}$ & $411(\mathrm{M}+1)^{+}$ \\
\hline
\end{tabular}


Table 1. Cont.

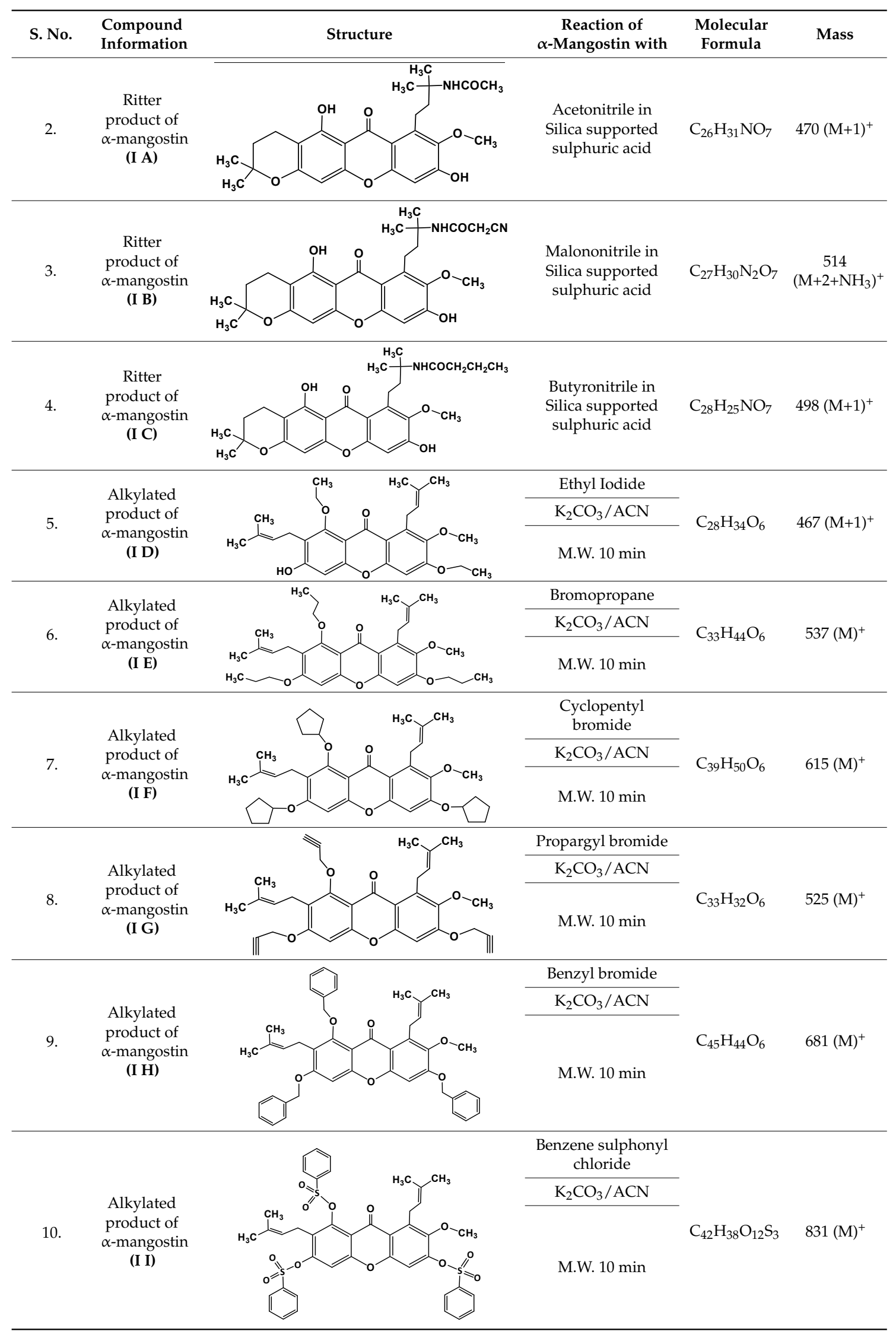


Table 1. Cont.

S. No. $\begin{gathered}\text { Compound } \\ \text { Information }\end{gathered}$

\subsection{Biological Assays}

\subsubsection{Anti-Bacterial Assay}

The evaluation of the anti-bacterial potential for $\alpha$-mangostin-based synthetic analogs was examined against E. coli, Bacillus subtilis (B. subtilis), S. aureus, and P. aeruginosa, in accordance with an experimental procedure. Two different concentrations $(50 \mu \mathrm{g} / \mathrm{mL}$ and $100 \mu \mathrm{g} / \mathrm{mL})$ of the $\alpha$-mangostin and their synthetic analogs along with standard drug Ciprofloxacin were tested against the pathogens and the results are given in Table 2. The zone of inhibition was determined in triplicates using the diffusion technique, with values representing the average zone of inhibition.

By measuring the zone of inhibition (in $\mathrm{mm}$ ), it is observed that all the derivatives of $\alpha$-mangostin exert moderate to high anti-bacterial activity. Compound (I E) showed maximum anti-bacterial activity (up to $12 \mathrm{~mm}$ ) at $100 \mu \mathrm{g} / \mathrm{mL}$ concentration against all bacterial stains tested in comparison to the other synthesized compounds. At low concentration of $50 \mu \mathrm{g} / \mathrm{mL}$, the acetyl derivative (I G) showed maximum inhibition against $E$. coli. The butyl derivative (I C) showed maximum inhibition against B. subtilis. The propenyl derivative (I G) showed maximum inhibition against $S$. aureus. The ethyl (I D) and benzene sulphonyl (I I) derivatives of $\alpha$-mangostin showed maximum inhibition against P. aeruginosa. Among these compounds, the acetyl (I K) and benzene sulphonyl (I I) derivatives of $\alpha$-mangostin showed maximum anti-bacterial activity against the four bacterial strains tested. Most of the derivatives showed better anti-bacterial activity against Gram-positive bacteria B. subtilis and S. aureus followed by the Gram-negative bacteria P. aeruginosa and E. coli. The agar disk-diffusion method may not be appropriate method to determine the minimum inhibitory concentration (MIC), as it is impossible to quantify the amount of the antimicrobial agent diffused into the agar medium. Since only two concentrations ( 50 and $100 \mu \mathrm{g} / \mathrm{mL}$ ) were tested, at this time we could not calculate the appropriate MIC value. Further experiments are required to evaluate the effective microbicidal concentrations, such as MBC tests. 
Table 2. Anti-microbial and anti-fungal activity of the $\alpha$-mangostin and their synthetic analogs.

\begin{tabular}{|c|c|c|c|c|c|c|c|c|c|c|c|c|}
\hline \multirow{3}{*}{$\begin{array}{c}\text { S. No. } \\
\text { Conc. }(\mu \mathrm{g} / \mathrm{mL})\end{array}$} & \multicolumn{12}{|c|}{ Zone of Inhibition in $\mathrm{mm}$} \\
\hline & \multicolumn{2}{|c|}{ E. coli } & \multicolumn{2}{|c|}{ B. subtilis } & \multicolumn{2}{|c|}{ S. aureus } & \multicolumn{2}{|c|}{ P. aeruginosa } & \multicolumn{2}{|c|}{ C. albicans } & \multicolumn{2}{|c|}{ A. niger } \\
\hline & 50 & 100 & 50 & 100 & 50 & 100 & 50 & 100 & 50 & 100 & 50 & 100 \\
\hline $\mathbf{I}$ & $5 \pm 0.09$ & $8 \pm 0.04$ & $7 \pm 0.11$ & $9 \pm 0.15$ & $5 \pm 0.05$ & $9 \pm 0.12$ & $6 \pm 0.24$ & $10 \pm 0.08$ & $8 \pm 0.12$ & $10 \pm 0.14$ & $4 \pm 0.18$ & $7 \pm 0.05$ \\
\hline I A & $4 \pm 0.18$ & $9 \pm 0.16$ & $6 \pm 0.15$ & $10 \pm 0.11$ & $5 \pm 0.12$ & $11 \pm 0.22$ & $5 \pm 0.11$ & $8 \pm 0.16$ & $7 \pm 0.11$ & $10 \pm 0.06$ & $9 \pm 0.11$ & $12 \pm 0.02$ \\
\hline I B & $6 \pm 0.14$ & $10 \pm 0.11$ & $6 \pm 0.12$ & $9 \pm 0.23$ & $5 \pm 0.16$ & $8 \pm 0.14$ & $4 \pm 0.08$ & $8 \pm 0.22$ & $4 \pm 0.16$ & $6 \pm 0.11$ & $3 \pm 0.07$ & $5 \pm 0.15$ \\
\hline I C & $8 \pm 0.11$ & $11 \pm 0.08$ & $10 \pm 0.06$ & $12 \pm 0.04$ & $6 \pm 0.18$ & $9 \pm 0.06$ & $5 \pm 0.16$ & $10 \pm 0.13$ & $2 \pm 0.16$ & $6 \pm 0.13$ & $2 \pm 0.18$ & $5 \pm 0.14$ \\
\hline I D & $7 \pm 0.12$ & $10 \pm 0.18$ & $4 \pm 0.04$ & $10 \pm 0.09$ & $5 \pm 0.08$ & $7 \pm 0.12$ & $9 \pm 0.21$ & $9 \pm 0.08$ & $4 \pm 0.22$ & $6 \pm 0.21$ & $7 \pm 0.15$ & $9 \pm 0.08$ \\
\hline I E & $6 \pm 0.13$ & $11 \pm 0.22$ & $9 \pm 0.15$ & $12 \pm 0.16$ & $7 \pm 0.22$ & $11 \pm 0.18$ & $7 \pm 0.05$ & $12 \pm 0.03$ & $4 \pm 0.08$ & $7 \pm 0.17$ & $3 \pm 0.04$ & $5 \pm 0.05$ \\
\hline I F & $6 \pm 0.18$ & $9 \pm 0.04$ & $5 \pm 0.09$ & $11 \pm 0.18$ & $7 \pm 0.14$ & $11 \pm 0.17$ & $5 \pm 0.09$ & $9 \pm 0.14$ & $3 \pm 0.07$ & $5 \pm 0.14$ & $4 \pm 0.09$ & $7 \pm 0.11$ \\
\hline I G & $6 \pm 0.20$ & $9 \pm 0.12$ & $7 \pm 0.05$ & $10 \pm 0.11$ & $10 \pm 0.21$ & $11 \pm 0.19$ & $6 \pm 0.14$ & $9 \pm 0.18$ & $4 \pm 0.12$ & $6 \pm 0.19$ & $3 \pm 0.16$ & $5 \pm 0.19$ \\
\hline I H & $5 \pm 0.12$ & $9 \pm 0.11$ & $6 \pm 0.12$ & $9 \pm 0.08$ & $8 \pm 0.18$ & $10 \pm 0.13$ & $8 \pm 0.11$ & $11 \pm 0.11$ & $9 \pm 0.17$ & $13 \pm 0.12$ & $7 \pm 0.11$ & $10 \pm 0.21$ \\
\hline I I & $5 \pm 0.08$ & $8 \pm 0.15$ & $6 \pm 0.04$ & $10 \pm 0.20$ & $7 \pm 0.11$ & $9 \pm 0.15$ & $9 \pm 0.19$ & $12 \pm 0.06$ & $10 \pm 0.14$ & $12 \pm 0.09$ & $9 \pm 0.08$ & $13 \pm 0.11$ \\
\hline I J & $4 \pm 0.15$ & $7 \pm 0.16$ & $5 \pm 0.11$ & $8 \pm 0.14$ & $4 \pm 0.13$ & $7 \pm 0.21$ & $3 \pm 0.08$ & $6 \pm 0.20$ & $11 \pm 0.12$ & $13 \pm 0.15$ & $6 \pm 0.03$ & $8 \pm 0.18$ \\
\hline I K & $10 \pm 0.14$ & $12 \pm 0.16$ & $4 \pm 0.10$ & $7 \pm 0.14$ & $5 \pm 0.08$ & $9 \pm 0.08$ & $6 \pm 0.22$ & $9 \pm 0.06$ & $8 \pm 0.20$ & $11 \pm 0.18$ & $10 \pm 0.15$ & $13 \pm 0.18$ \\
\hline I L & $9 \pm 0.13$ & $11 \pm 0.06$ & $5 \pm 0.21$ & $8 \pm 0.16$ & $5 \pm 0.12$ & $8 \pm 0.05$ & $6 \pm 0.15$ & $8 \pm 0.12$ & $7 \pm 0.13$ & $10 \pm 0.08$ & $9 \pm 0.17$ & $12 \pm 0.08$ \\
\hline Std drug & $19 \pm 0.11$ & $24 \pm 0.05$ & $16 \pm 0.07$ & $20 \pm 0.14$ & $11 \pm 0.15$ & $18 \pm 0.06$ & $15 \pm 0.12$ & $19 \pm 0.16$ & $15 \pm 0.16$ & $18 \pm 0.04$ & $14 \pm 0.13$ & $18 \pm 0.08$ \\
\hline
\end{tabular}




\subsubsection{Anti-Fungal Assay}

The first compound evaluated was the natural product $\alpha$-mangostin, which was compared against the synthetic analogs to prove that the analogs had better efficacy than the parent molecule. Two compounds, I $\mathbf{H}$ and I J , at $100 \mu \mathrm{g} / \mathrm{mL}$ concentration, showed maximum anti-fungal activity against Candida albicans, with a $13 \mathrm{~mm}$ inhibition halo, in respect to the other tested compounds. In addition, among all derivatives of $\alpha$-mangostin, the acetyl (I K) and benzene sulphonyl (I I) derivatives at $100 \mu \mathrm{g} / \mathrm{mL}$ concentration displayed maximum inhibition of $13 \mathrm{~mm}$ against Aspergillus niger (Table 2). The zone of inhibition was determined in triplicates using the diffusion technique, with values representing the average zone of inhibition. The alkylated product of $\alpha$-mangostin (I I) showed the most significant activity against fungal strains, with $12 \mathrm{~mm}$ inhibition of C. albicans and $13 \mathrm{~mm}$ inhibition of $A$. niger. The xanthonoid skeleton with benzene sulphonyl moiety showed enhanced anti-fungal activity for $\alpha$-mangostin-based derivatives.

The cytotoxicity studies were carried out in silico using a software to individuate reactive groups as from databases on chemical compounds. The in silico toxicity was predicted using the Toxtree implementation of the modified Cramer rules and Verhaar scheme. The software Toxtree v.2.6.13 (IdeaConsult Ltd., Sofia, Bulgaria), along with Cramer rules and Verhaar scheme, were run to study the toxicity of organic molecules [55-59]. The module was developed for the Long-Range Research Initiative (LRI) and European Chemical Industry Council (CEFIC) CEFIC-LRI project AMBIT for a new open software tool. A typical evaluation is given for one of the products. The study showed all the molecules to be non-toxic. However this has to be validated by in vitro or in vivo studies which are beyond the scope of the present study. Indeed such studies will form part of an in depth evaluation of potential molecules. The in silico studies for compounds I A-C are attached as separate file named "Mangostin and derivatives IA-IC in silico studies". An example of results of cytotoxicity studies is presented in the Supplementary file S2, "I A, I B, I C $\alpha$-mangostin derivatives in silico toxicity test".

\section{Discussion}

In this study the semi-synthetically modified $\alpha$-mangostin-derived compounds were shown to exhibit bioactive properties and antimicrobial activity greater than the parent natural molecule when tested against various microbial and fungal cultures. Due to their anti-microbial properties, they can be utilized as wound healers and in the treatment of skin infections, and in packaging materials for the extension of food shelf life. We have shown the semi-synthetic modification of $\alpha$-mangostin using the Ritter reaction reduction by palladium-carbon (Pd-C), alkylation, and acetylation.

Studies are ongoing in the field of materials for packaging, to extend the shelf-life of food products. The biomedical industry is also interested in a safe way for the containment of biofilm formation, and production of devices with potential to avoid bacterial growth. Textiles, polymer films, and wrapping materials are manufactured by electro-spinning and layer-by-layer deposition, the first one better suited to eliminate residual solvents. The perishable foods represent a loss due to fungal and bacterial growth, requiring short times from the shelves to the table. Thus, improvement in treatments and use of anti-fungal films may ensure higher safety standard for human health in addition to decrease of economic losses at retailer shops and during food supply chain. It is expected that new materials and films, based on available and novel, semi-synthetic antimicrobial compounds, after assessment of safety for humans or animals, grade of release of antimicrobials during the time, may find their application according to the industry needs.

$\alpha$-Mangostin and derived semi-synthesis products have been shown in several studies to have the potential to be exploited as antimicrobial agents. In this study, twelve $\alpha$-mangostin derivatives were analyzed for inhibition of two Gram-positive and two Gram-negative bacteria (using Ciprofloxacin as a reference drug at 50 and $100 \mu \mathrm{g} / \mathrm{mL}$ ) and two fungal pathogens (using Ketoconazol as a reference drug at 50 and $100 \mu \mathrm{g} / \mathrm{mL}$ ) to determine the sensitivity of each bacterial species.

Looking for derivatives with improved activity in respect to the original compound $\alpha$-mangostin xanthone. Starting from this preliminary characterization, it will be possible to test these compounds 
in vitro and in vivo, on animal models, to check the safety of the compounds, and to evaluate the inhibition of bacterial growth, such as a bactericide activity on infected wounds. The antimicrobial compounds, such as I E, have been shown to have inhibitory activity and need to be studied further for applications in healthcare.

\section{Materials and Methods}

\subsection{Isolation and Purification of $\alpha$-Mangostin from Mangoosteen Fruit}

All of the chemicals and reagents were purchased from either Sigma-Aldrich (St. Louis, MO, USA) or Merck (Darmstadt, Germany) chemicals. The extraction of $\alpha$-mangostin from the dried fruits of G. mangostana was carried out with Soxhlet extraction methodology. A known weight (100 g) of the fruit hulls was used, and extracted twice with $300 \mathrm{~mL}$ of ethyl acetate. The extract was filtered through a Whatman filter paper No.1 (Brentford, UK) by suction. The filtrate was concentrated under reduced pressure to obtain the ethyl acetate crude extract $(26 \mathrm{~g})$. Then $20 \mathrm{~g}$ of ethyl acetate crude extract was subjected to TLC column chromatography using ethyl acetate and hexane (1:1) as the eluent. The fractions containing $\alpha$-mangostin were pooled and evaporated to obtain a solid of $95 \%$ purity by HPLC (High Performance Liquid Chromatography). The obtained solid fraction was used as starting material for semi-synthetic modification and for microbial studies. The compound was repeatedly recrystallized using benzene for structural characterization using ${ }^{1} \mathrm{H}-\mathrm{NMR}$ spectra, ${ }^{13} \mathrm{C}-\mathrm{NMR}$ spectra, and high-resolution mass spectra.

\subsection{General Methods for Compound Analysis}

The purity of the isolated $\alpha$-mangostin and the progress of the reaction was monitored by HPLC on analytical reversed phase develosil ODS column C18 (150 mm $\times 4.6 \mathrm{~mm}, 0.5 \mu \mathrm{m})$ using $0.02 \mathrm{M}$ potassium dihydrogen phosphate in water and a acetonitrile 50:50 ratio as the mobile phase, with $1.0 \mathrm{~mL} / \mathrm{min}$ flow rate for $30 \mathrm{~min}$, and a UV detector wavelength of $254 \mathrm{~nm}$. The main product was analyzed by nuclear magnetic resonance (NMR) $\left({ }^{1} \mathrm{H}: 400 \mathrm{MHz},{ }^{13} \mathrm{C}: 100 \mathrm{MHz}\right)$ and data recorded on a Bruker instrument (Billerica, MA, USA), with chemical shifts expressed in $\delta$ ppm. NMR spectra were obtained in MeOD with tetramethylsilane (TMS) as a reference compound. Mass was determined using a Shimadzu analyzer (Columbia, MD, USA).

\subsection{Anti-Microbial Activity Assay}

The study of anti-microbial activity of the synthetic analogs was performed by measuring the diameter of the inhibition halo from the outer surface of the disc, expressed in millimeters. The zone of inhibition of the $\alpha$-mangostin was compared with its synthetic analogs to determine the rate of inhibition. The zone of inhibition was determined in triplicates using the diffusion technique, with values representing the average zone of inhibition. The nutrient broth medium $(50 \mathrm{~mL})$ was prepared and sterilized in autoclave at $121^{\circ} \mathrm{C}$ for $15 \mathrm{~min}$. Gram-positive bacteria (B. subtilis and S. aureus) and Gram-negative bacteria (E. coli and P. aeruginosa) were inoculated in tubes of nutrient broth, whereas the fungal cultures (C. albicans and $A$. niger) were inoculated in tubes of potato dextrose agar, and incubated at $37^{\circ} \mathrm{C}$ for $24 \mathrm{~h}$; then the suspension was centrifuged at $8000 \times g$ for $5 \mathrm{~min}$, the pellet was suspended in double-distilled water, and the cell density was standardized spectrophotometrically $\left(\mathrm{A}_{610} \mathrm{~nm}\right)$. All of the microbial cultures were adjusted to $0.5 \mathrm{McFarland}$ standards, which is visually comparable to a microbial suspension of approximately $1.5 \times 10^{8} \mathrm{cfu} / \mathrm{mL}$.

\subsubsection{Anti-Bacterial Assay}

The bacterial species, chosen as representatives of spoilage and pathogenic species commonly found contaminating surfaces and workplaces, were used to evaluate the anti-bacterial activities of the synthetic compounds. The bacteria were maintained on Muller Hilton broth media at $37^{\circ} \mathrm{C}$. Then, Muller Hilton agar plates were swabbed with $100 \mu \mathrm{L}$ inocula of the test microorganisms 
and kept for $15 \mathrm{~min}$ for absorption. Six-millimeter Whatman No. 1 discs were pre-sterilized and two concentrations (50 and $100 \mu \mathrm{g} / \mathrm{mL}$ ) of the test compounds in DMSO were applied to the sterile disc papers. The standard drug Ciprofloxacin $(50$ and $100 \mu \mathrm{g})$ was used as a positive reference standard to determine the sensitivity of each bacterial species. Then the plates were inoculated at $37^{\circ} \mathrm{C}$ for $24 \mathrm{~h}$.

\subsubsection{Anti-Fungal Assay}

All of the synthesized compounds were screened for anti-fungal activity by disc diffusion method. PDA medium was autoclaved at $121^{\circ} \mathrm{C}$ for $15 \mathrm{~min}$ and poured into each Petri plate and the solidified media plates were swabbed with $0.2 \mathrm{~mL}$ of fungal cultures. Six-millimeter Whatman No. 1 discs were loaded with the test compounds in DMSO at 50 and $100 \mu \mathrm{g} / \mathrm{mL}$ concentration. Then the plates were inoculated at $28^{\circ} \mathrm{C}$ for $72 \mathrm{~h}$. The diameter of the clear zone around the well was measured and expressed in millimeters. Standard drug Ketoconazole (50 and $100 \mu \mathrm{g}$ ) was used as a positive reference standard to determine the sensitivity of each fungal species.

\section{Conclusions}

Among the semi-synthetic derivatives of $\alpha$-mangostin, I E showed higher anti-bacterial activity whereas I I showed the most significant anti-fungal activity. These compounds pave the way to the synthesis of non-toxic compounds with better efficacy compared to the natural product for anti-microbial treatment. It is envisaged that these new anti-microbial compounds could be incorporated in packaging materials, textiles, biomedical devices, and film polymers, to improve the microbiological safety of surfaces in contact with bacteria.

Supplementary Materials: The following are available online. Figure S1: title Molecules Narasimhan Poltronieri supplementary.doc in Supplementary.zip. Supplementary materials include ${ }^{1} \mathrm{H}-\mathrm{NMR}$ spectra, ${ }^{13} \mathrm{C}-\mathrm{NMR}$ spectra, and high-resolution mass spectra for compounds I, I A-I L. Supplementary materials can be accessed from the $\mathrm{PhD}$ thesis "Studies on isolation and the semi-synthetic modification of bio active molecules from G. mangostana and Embelia ribes" submitted in partial fulfillment of the requirements for the degree of Doctor of Philosophy by S. Maheshwaran, under the guidance of Dr. S. Narasimhan at the University of Madras (April 2013). Supplementary word file S2: "I A, I B, I C $\alpha$-mangostin derivatives in silico toxicity test".

Acknowledgments: We declare no private funding for this work. P.P. was suportedc by the Italian Ministry for Innovation: PON02_00186_3417512 S.I.Mi.S.A. Innovative instruments for the improvement of food safety.

Author Contributions: N.S. designed the experiments and supervised their execution. S.M. performed the chemical modifications. I.A.A.Y., A.F.M. and J.R. performed the structure analyses. P.E.D. performed data analyses. P.P. designed and supervised the microbiological assays done by S.M. All authors contributed to manuscript writing and preparation.

Conflicts of Interest: The authors declare no conflicts of interest.

\section{References}

1. Martin, F.W. Durian and mangosteen. In Tropical and Subtropical Fruits: Composition, Properties and Uses; Nagy, S., Shaw, P.E., Eds.; The AVI Publishing Company, Inc.: Westport, CT, USA, 1980; pp. 407-414.

2. Kanchanapoom, K.; Kanchanapoom, M. Mangosteen. In Tropical and Subtropical Fruits; Shaw, P.E., Chan, H.T., Nagy, S., Eds.; Agscience Inc.: Auburndale, FL, USA, 1998; pp. 191-215.

3. Suksamrarn, S.; Komutiban, O.; Ratananukul, P.; Chimnoi, N.; Lartpornmatulee, N.; Suksamrarn, A. Cytotoxic prenylated xanthones from the young fruit of Garcinia mangostana. Chem. Pharm. Bull. 2006, 54, 301-305. [CrossRef] [PubMed]

4. Pedraza-Chaverri, J.; Cárdenas-Rodríguez, N.; Orozco-Ibarra, M.; Pérez-Rojas, J.M. Medicinal properties of mangosteen (Garcinia mangostana). Food Chem. Toxicol. 2008, 46, 3227-3239. [CrossRef] [PubMed]

5. Iinuma, M.; Tosa, H.; Tanaka, T.; Asai, F.; Kobayashi, A.; Shimano, R.; Miyauchi, K.-I. Antibacterial activity of xanthones from guttiferaeous plants against methicillin-resistant Staphylococcus aureus. J. Pharm. Pharmacol. 1996, 48, 861-865. [CrossRef] [PubMed] 
6. Duangsrisai, S.; Choowongkomon, K.; Bessa, L.; Costa, P.; Amat, N.; Kijjoa, A. Antibacterial and EGFR-tyrosine kinase inhibitory activities of polyhydroxylated xanthones from Garcinia succifolia. Molecules 2014, 19, 19923-19934. [CrossRef] [PubMed]

7. Chomnawang, M.T.; Surassmo, S.; Nukoolkarn, V.S.; Gritsanapan, W. Antimicrobial effects of Thai medicinal plants against acne-inducing bacteria. J. Ethnopharmacol. 2005, 101, 330-333. [CrossRef] [PubMed]

8. Lebedeva, A.A.; Zakharchenko, N.S.; Trubnikova, E.V.; Medvedeva, O.A.; Kuznetsova, T.V.; Masgutova, G.A.; Zylkova, M.V.; Buryanov, Y.I.; Belous, A.S. Bactericide and immunomodulating properties of transgenic Kalanchoe pinnata synergize with antimicrobial peptide cecropin P1 in vivo. J. Immunol. Res. 2017, in press.

9. Miguel-de Abreu, P.; Farias, P.G.; Paliva, G.S.; Almeida, A.M.; Morals, P.V. Persistence of microbial communities including Pseudomonas aeruginosa in a hospital environment: A potential health hazard. BMC Microbiol. 2014, 14, 118.

10. Jain, A.; Agarwal, A.; Verma, R.K. Cefoxitin Disc diffusion test for detection of methicillin-resistant Staphylococci. J. Med. Microbiol. 2008, 57, 957-961. [CrossRef] [PubMed]

11. Walker, E.B. HPLC analysis of selected xanthones in mangosteen fruit. J. Separ. Sci. 2007, 30, 1229-1234. [CrossRef] [PubMed]

12. Mohamed, G.A.; Ibrahim, S.R.M.; Shaaban, M.I.A.; Ross, S.A. Mangostan axanthones I and II, new xanthones from the pericarp of Garcinia mangostana. Phytotherapia 2014, 98, 215-221.

13. Sakagami, Y.; Iinuma, M.; Piyasena, K.G.; Dharmaratne, H.R. Antibacterial activity of alpha-mangostin against vancomycin resistant Enterococci (VRE) and synergism with antibiotics. Phytomedicine 2005, 12, 203-208. [CrossRef] [PubMed]

14. Phitaktim, S.; Chomnawang, M.; Sirichaiwetchakoon, K.; Dunkhunthod, B.; Hobbs, G.; Eumkeb, G. Synergism and the mechanism of action of the combination of $\alpha$-mangostin isolated from Garcinia mangostana L. and oxacillin against an oxacillin-resistant Staphylococcus saprophyticus. BMC Microbiol. 2016, 16, 195. [CrossRef] [PubMed]

15. Ragasa, C.Y.; Crisostomo, C.J.J.; Garcia, K.D.C.; Shen, C. Antimicrobial xanthones from Garcinia mangostana L. Philipp. Sci. 2010, 47, 63-75.

16. Alsultan, Q.M.N.; Sijam, K.; Rashid, T.S.; Ahmad, K.B. GC-MS Analysis and antibacterial activity of mangosteen leaf extracts against plant pathogenic bacteria. Am. J. Plant Sci. 2016, 7, 1013-1020. [CrossRef]

17. Tatiya-Aphiradee, N.; Chatuphonprasert, W.; Jarukamjorn, K. In vivo antibacterial activity of Garcinia mangostana pericarp extract against methicillin-resistant Staphylococcus aureus in a mouse superficial skin infection model. Pharm. Biol. 2016, 54, 2606-2615. [CrossRef] [PubMed]

18. Dharmaratne, H.R.W.; Sakagami, Y.; Piyasena, K.G.P.; Thevanesam, V. Antibacterial activity of xanthones from Garcinia mangostana (L.) and their structure-activity relationship studies. Nat. Prod. Res. 2013, 27, 938-941. [CrossRef] [PubMed]

19. Weecharangsan, W.; Opanasopit, P.; Sukma, M.; Ngawhirunpat, T.; Sotanaphun, U.; Siripong, P. Antioxidative and neuroprotective activities of extracts from the fruit hull of mangosteen (Garcinia mangostana Linn.). Med. Princ. Pract. 2006, 15, 281-287. [CrossRef] [PubMed]

20. Guzmán-Beltrán, S.; Orozco-Ibarra, M.; González-Cuahutencos, O.; Victoria-Mares, S.; Merchand-Reyes, G.; Medina-Campos, O.N.; Pedraza-Chaverri, J. Neuroprotective effect and reactive oxygen species scavenging capacity of mangosteen pericarp extract in cultured neurons. Curr. Top. Nutr. Res. 2008, 6, 149-158.

21. Márquez-Valadez, B.; Lugo-Huitrón, R.; Valdivia-Cerda, V.; Miranda-Ramírez, L.R.; Pérez-De La Cruz, V.; González-Cuahutencos, O.; Rivero-Cruz, I.; Mata, R.; Santamaría, R.; Pedraza-Chaverrí, J. The natural xanthone $\alpha$-mangostin reduces oxidative damage in rat brain tissue. Nutr. Neurosci. 2009, 12, 35-42. [CrossRef] [PubMed]

22. Pedraza-Chaverrí, J.; Reyes-Fermín, L.M.; Nolasco-Amaya, E.G.; Ibarra, M.O.; Medina-Campos, O.N.; González-Cuahutencos, O.; Rivero-Cruz, I.; Mata, R. ROS scavenging capacity and neuroprotective effect of $\alpha$-mangostin against 3-nitropropionic acid in cerebellar granule neurons. Exp. Toxicol. Pathol. 2009, 61, 491-501. [CrossRef] [PubMed]

23. Chae, H.-S.; Kim, E.-Y.; Han, L.; Kim, N.-R.; Lam, B.; Paik, J.H.; Yoon, K.D.; Choi, Y.H.; Chin, Y.-W. Xanthones with pancreatic lipase inhibitory activity from the pericarps of Garcinia mangostana L. (Guttiferae). Eur. J. Lipid Sci. Technol. 2016, 118, 1416-1421. [CrossRef] 
24. Balunas, M.J.; Su, B.; Brueggemeier, R.W.; Kinghorn, A.D. Xanthones from the botanical dietary supplement mangosteen (Garcinia mangostana) with aromatase inhibitory activity. J. Nat. Prod. 2008, 71, 1161-1166. [CrossRef] [PubMed]

25. Lin, C.N.; Chung, M.I.; Liou, S.J.; Lee, T.H.; Wang, J.P. Synthesis and anti-inflammatory effects of xanthone derivatives. J. Pharm. Pharmacol. 1996, 48, 532-538. [CrossRef] [PubMed]

26. Chin, Y.W.; Kinghorn, A.D. Structural characterization, biological effects, and synthetic studies on xanthones from mangosteen (Garcinia mangostana), a popular botanical dietary supplement. Mini. Rev. Org. Chem. 2008, 5, 355-364. [CrossRef] [PubMed]

27. Fei, X.; Jo, M.; Lee, B.; Han, S.; Lee, K.; Jung, J.; Seo, S.; Kwak, Y. Synthesis of xanthone derivatives based on $\alpha$-mangostin and their biological evaluation for anti-cancer agents. Bioorg. Med. Chem. Lett. 2014, 24, 2062-2065. [CrossRef] [PubMed]

28. Morelli, C.F.; Biagiotti, M.; Pappalardo, V.M.; Rabuffetti, M.; Speranza, G. Chemistry of $\alpha$-mangostin. Studies on the semisynthesis of minor xanthones from Garcinia mangostana. Nat. Product Res. 2015, 29, 750-755. [CrossRef] [PubMed]

29. Zou, H.; Koh, J.; Li, J.; Qiu, S.; Aung, T.T.; Lin, H.; Lakshminarayanan, R.; Dai, X.; Tang, C.; Lim, F.H.; et al. Design and synthesis of amphiphilic xanthone-based, membrane-targeting antimicrobials with improved membrane selectivity. J. Med. Chem. 2013, 56, 2359-2373. [CrossRef] [PubMed]

30. Samprasit, W.; Rojanarata, T.; Akkaramongkolporn, P.; Ngawhirunpat, T.; Kaomongkolgit, R.; Opanasopit, P. Fabrication and in vitro/in vivo performance of mucoadhesive electrospun nanofiber mats containing $\alpha$-mangostin. AAPS Pharm. Sci. Tech. 2015, 16, 1140-1152. [CrossRef] [PubMed]

31. Suwantong, O.; Pankongadisak, P.; Deachathai, S.; Supaphol, P. Electrospun poly(L-lactic acid) fiber mats containing crude Garcinia mangostana extracts for use as wound dressings. Polym. Bull. 2014, 71, 925-949. [CrossRef]

32. Lakouraj, M.M.; Rahpaima, G.; Mohseni, M. Synthesis, characterization, metal sorption, and biological activities of organosoluble and thermally stable azoxanthone-based polyester. Polym. Adv. Technol. 2015, 26, 234-244. [CrossRef]

33. Vimala, K.; Yallapu, M.M.; Varaprasad, K.; Reddy, N.N.; Ravindra, S.; Naidu, N.S.; Raju, K.M. Fabrication of curcumin encapsulated chitosan-PVA silver nanocomposite films for improved antimicrobial activity. J. Biomater. Nanobiotechnol. 2011, 2, 55-64. [CrossRef]

34. Mun, S.H.; Joung, D.K.; Kim, Y.S.; Kang, O.H.; Kim, S.B.; Seo, Y.S.; Kwon, D.Y. Synergistic antibacterial effect of curcumin against methicillin-resistant Staphylococcus aureus. Phytomedicine 2013, 20, 714-718. [CrossRef] [PubMed]

35. Shlar, I.; Poverenov, E.; Vinokur, Y.; Horev, B.; Droby, S.; Rodov, V. High throughput screening of nanoparticle-stabilizing ligands: Application to preparing antimicrobial curcumin nanoparticles by antisolvent precipitation. Nano-Micro Lett. 2015, 7, 68-79. [CrossRef]

36. Dogra, N.; Choudhary, R.; Kohli, P.; Haddock, J.D.; Makwana, S.; Horev, B.; Vinokur, Y.; Droby, S.; Rodov, V. Polydiacetylene nanovesicles as carriers of natural phenylpropanoids for creating antimicrobial food-contact surfaces. J. Agric. Food Chem. 2015, 63, 2557-2565. [CrossRef] [PubMed]

37. Ravichandran, M.; Hettiarachchy, N.S.; Ganesh, V.; Ricke, S.C.; Singh, S. Enhancement of antimicrobial activities of naturally occurring phenolic compounds by nanoscale delivery against Listeria monocytogenes, Escherichia coli O157:H7 and Salmonella typhimurium in broth and chicken meat system. J. Food Saf. 2011, 31, 462-471. [CrossRef]

38. Fitzgerald, D.J.; Stratford, M.; Gasson, M.J.; Ueckert, J.; Bos, A.; Narbad, A. Mode of antimicrobial action of vanillin against Escherichia coli, Lactobacillus plantarum and Listeria innocua. J. Appl. Microbiol. 2004, 97, 104-113. [CrossRef]

39. Rodov, V.; Nafussi, B.; Ben-Yehoshua, S. Essential oil components as potential means to control postharvest pathogens of citrus fruit. Fresh Prod. 2011, 5, 43-50.

40. Horev, B.; Sela, S.; Vinokur, Y.; Gorbatsevich, E.; Pinto, R.; Rodov, V. The effects of active and passive modified atmosphere packaging on the survival of Salmonella enterica serotype Typhimurium on washed romaine lettuce leaves. Food Res. Int. 2012, 45, 1129-1132. [CrossRef]

41. Izumi, H.; Rodov, V.; Bai, J.; Wendakoon, S. Physiology and quality of fresh-cut produce in CA/MA storage. In Fresh-Cut Fruit and Vegetables: Physiology, Technology and Safety, 1st ed.; Pareek, S., Ed.; CRC Press: Boca Raton, FL, USA, 2016; pp. 271-318. 
42. Fadida, T.; Kroupitski, Y.; Peiper, U.M.; Bendikov, T.; Sela, S.; Poverenov, E. Air-ozonolysis to generate contact active antimicrobial surfaces: Activation of polyethylene and polystyrene followed by covalent graft of quaternary ammonium salts. Colloids Surf. B Biointerfaces 2014, 122, 294-300. [CrossRef] [PubMed]

43. Reidy, B.; Haase, A.; Luch, A.; Dawson, K.A.; Lynch, I. Mechanisms of silver nanoparticle release, transformation and toxicity: A critical review of current knowledge and recommendations for future studies and applications. Materials 2013, 6, 2295-2350. [CrossRef]

44. Malka, E.; Perelshtein, I.; Lipovsky, A.; Shalom, Y.; Naparstek, L.; Perkas, N.; Patick, T.; Lubart, R.; Nitzan, Y.; Banin, E.; et al. Eradication of multi-drug resistant bacteria by a novel Zn-doped CuO nanocomposite. Small 2013, 9, 4069-4076. [CrossRef] [PubMed]

45. Meridor, D.; Gedanken, A. Preparation of enzyme nanoparticles and studying the catalytic activity of the immobilized nanoparticles on polyethylene films. Ultrason. Sonochem. 2013, 20, 425-431. [CrossRef] [PubMed]

46. Poverenov, E.; Danino, S.; Horev, B.; Granit, R.; Vinokur, Y.; Rodov, V. Layer-by-Layer electrostatic deposition of edible coating on fresh cut melon model: Anticipated and unexpected effects of alginate-chitosan combination. Food Bioprocess Technol. 2014, 7, 1424-1432. [CrossRef]

47. Poverenov, E.; Rutenberg, R.; Danino, S.; Horev, B.; Rodov, V. Gelatin-chitosan composite films and edible coatings to enhance the quality of food products: Layer-by-Layer vs. blended formulations. Food Bioprocess Technol. 2014, 7, 3319-3327. [CrossRef]

48. Poverenov, E.; Shemesh, M.; Gulino, A.; Cristaldi, D.A.; Zakin, V.; Yefremov, T.; Granit, R. Durable contact active antimicrobial materials formed by a one-step covalent modification of polyvinyl alcohol, cellulose and glass surfaces. Colloids Surf. B Biointerfaces 2013, 112, 356-361. [CrossRef] [PubMed]

49. Chung, D.; Papadakis, S.E.; Yam, K.L. Evaluation of a polymer coating containing triclosan as the antimicrobial layer for packaging materials. Int. J. Food Sci. Technol. 2003, 38, 165-169. [CrossRef]

50. Bastarrachea, L.; Dhawan, S.; Sablani, S.S. Engineering properties of polymeric based antimicrobial films for food packaging: A review. Food Eng. Rev. 2011, 3, 79-93. [CrossRef]

51. Kurt, P.; Wood, L.; Ohman, D.E.; Wynne, K.J. Highly effective contact antimicrobial surfaces via polymer surface modifiers. Langmuir 2007, 23, 4719-4723. [CrossRef] [PubMed]

52. Zhang, F.; Kang, E.T.; Neoh, K.G.; Wang, P.; Tan, K.L. Surface modification of stainless steel by grafting of poly(ethylene glycol) for reduction in protein adsorption. Biomaterials 2001, 22, 1541-1548. [CrossRef]

53. El-Seedi, H.R.; El-Ghorab, D.M.H.; El-Barbary, M.A.; Zayed, M.F.; Goransson, U.; Larsson, S.; Veerporte, R. Naturally occurring xanthones; latest investigations: Isolation, structure elucidation and chemosystematic significance. Curr. Med. Chem. 2009, 16, 2581-2626. [CrossRef] [PubMed]

54. Jyoshna; Khare, P.; Shanker, K. Mangiferin: A review of sources and interventions for biological activities. BioFactors 2016, 42, 504-514. [CrossRef] [PubMed]

55. Cramer, G.M.; Ford, R.A.; Hall, R.L. Estimation of Toxic Hazard-A Decision Tree Approach. J. Cosmet. Toxicol. 1978, 16, 255-276. [CrossRef]

56. Patlewicz, G.; Jeliazkova, N.; Safford, R.J.; Worth, A.P.; Aleksiev, B. An evaluation of the implementation of the Cramer classification scheme in the Toxtree software. SAR QSAR Environ. Res. 2008, 19, 495-524. [CrossRef] [PubMed]

57. Lapenna, S.; Worth, A. Analysis of the Cramer Classification Scheme for Oral Systemic Toxicity-Implications for Its Implementation in Toxtree; EUR 24898 EN; Publications Office of the European Union: Luxembourg, 2011.

58. Verhaar, H.J.M.; van Leeuwen, C.J.; Hermens, J.L.M. Classifying environmental pollutants. 1. Structure-activity relationships for prediction of aquatic toxicity. Chemosphere 1992, 25, 471-491. [CrossRef]

59. Verhaar, H.J.M.; Solbe, J.; Speksnijder, J.; van Leeuwen, C.J.; Hermens, J.L.M. Classifying environmental pollutants: Part 3. External validation of the classification system. Chemosphere 2000, 40, 875-883. [CrossRef]

Sample Availability: Samples of the compounds I and I A to I L are available from the authors. 